\title{
Screening and peculiarity of the biological action of synthetic plant growth regulators
}

\author{
V. A. Tsygankova, Ya. B. Blume \\ Institute of Cell Biolcgy and Genetic Engineering, National Academy of Sciences of Ukraine \\ 148 Zabolotnogo sír., 252143, Kiev
}

\begin{abstract}
As a result of biological screening among synthetic compounds that have growth regulatory activities in culture tissues in vitro and in vivo in plants, 5 perspective substances were chosen as the substitutes of phytohormones. Thus, it was found that Ivin ( $N$-oxide 2,6-dimethylpyridine) revealed predominant cytokinin activity in vitro and a cytokinin-gibberelin activity in vivo; Methyur (Na-derivative 6methylthyouracyl) showed an expressive cytokinin-gibberellin activity in vivo; Triamelon (ladide tris (2,2-trimethylammoniummethyl phosphate) revealed a cytokinin-auxin activity in vitro; preparation D-107 (1-acetylamino-1-acetylthyo-2-oxo-2-phenylethan) revecled an auxine-like effect and the preparation $N$ 2622 (derivative tetrahydrothyophendioxide) showed an expressive auxin activity in vivo. The model of mediated action of plant growth regulators through phytohormones is proposed.
\end{abstract}

Introduction. The most important problem of cell biology and biotechnology is the substitution of expensive natural plant growth regulators (phytohormones) by synthetic compounds $[1-6]$. The worldwide experiments in substitution of natural phytohormones with artificial preparations (2,4-D, NAA, NOAA, BAP) confirm a perspective this approach.

Al the long time in the Institute of Organic Chemistry and Institute of Bioorganic and Petroleum Chemistry of National Academy of Sciences of Ukraine the synthesis and screening of plant growth regulators are the significant direction of scientific investigations.

For the biological screening of substances with growth-regulative activity synthezing in these Institutes we proposed to use the following test-systems: 1) cultures of isolated plant tissues of family Solanaceae (tobarco, tomato and potato) for which conditions of induction callus tissue formation in vitro from differentiated cells, organogenesis and regeneration of plants from cells of callus tissues were determinated in detail (i. e. compositions of nutrient media and which from phytohormones or its combination produce each of these processes) $[7-9]$; 2) embryo seeds and leaf grafts of vegetating plants of

(C) V. A. TSYGANKOVA, YA. B. BLUME, 1997 haricot that were used for a determination of phytohormones activities in vivo tests $[10,11]$.

Using above mentioned models at least 5 compounds Ivin ( $\mathrm{N}$-oxide 2,6-dimethylpyridine), Methyur (Na-derivative 6-methylthyouracyl), substance Triamelon (N 2863) (Iodide tris (2,2-trimethylammoniummethyl phosphate)), D-107 (1-Acetylamino1-acetylthyo-2-oxo-2-phenylethan), substance N 2622 (derivative tetrahydrothyophendioxide) is under patent procedure, have been chosen as perspective substitutions of some phytohormones for the practical purposes.

Materials and Methods. Chemical structures of chosen compounds are presented in the scheme.

Plant material. There are tobacco Nicotiana tabacum (varieties R-1; SR-2, visconsinia), potato Solanum tuberosum (varieties Zarevo and Nevskiy) and 2 types of tomato: cultural species (Lycopersicon esculentum) of mutant line MO 393 and wild Peruvian tomato ( $L$. peruvianum var. dentatum 3767 ) were used in test in vitro.

Before introducing in the culture the plant tissues (leaf or stem tissues) were sterilized with diocid (or hypochloride) and $70 \%$ ethanol and then washed with sterile distilled water.

For in vivo experiments seeds of asparagus haricot of Belozernaya (Phaseolus vulgaris L.) were used.

Seeds were germinated in humid atmosphere in 
Scheme<smiles></smiles>

lin<smiles>Cc1cccc(CCl)[n+]1O[Cl+3]</smiles>

$l i m-h$<smiles>Cc1cccc(CC(=O)C(=O)O)[n+]1O</smiles>
Firs.s

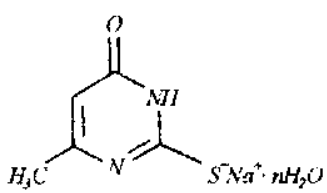

Methyn<smiles>CC(=O)NC(NC(C)=O)C(C)=O</smiles>

$0-107$

$O=\mu H O H_{2} \mathrm{CH}_{3} \mathrm{~N}^{\prime}\left(\mathrm{CH}_{3} \mathrm{~s}_{3} / \cdot 3 i\right.$

Triomsion special trays in the thermostat at $25-26{ }^{\circ} \mathrm{C}$ during $2-3$ days, and then seedlings were placed in the light box.

The vegetation lasted a week at 4000-6000 luxes, $22-24$ 'C and 16 hours' light day. An auxin activity was determined by Turetskaya method [10]. Leaf grafts of 12-14 day plants of haricot were placed in aqueous solutions of investigated substances. Every time 2 parallel experiments each with 5 grafts were made.

Cultural media for plant tissues. Modified nut- rient media ( $\mathrm{RMKU}$; RMOP; NP; RMB; RMO), on the basis of elaborated by Murashige and Skoog (MS); Gamborg et al. (B5) and medium of Linsmaier, Skoog (LS) containing similar to MS macro- and microelements compositions were used. Names and compositions of the media were taken from ref. [9]. To prepare the nutrient media the initial concentrated solutions were used: 1) 10 times solution of macrosalts; 2) 100 times solution of microsalts (besides salt solutions of $\mathrm{CoCl}_{2} \times 6 \mathrm{H}_{2} \mathrm{O}$ and $\mathrm{CuSO}_{4} \times 5 \mathrm{H}_{2} \mathrm{O}$ were prepared separately by a consistent dissolving of $25 \mathrm{mg}$ of each salt in $10 \mathrm{ml}$ of water. Then they were united with solution of other microsalts. General volume was increased to $100 \mathrm{ml}$ ); 3) an initial solution of Fe-helat was prepared by a consistent dissolving $7.45 \mathrm{~g}$ of $\mathrm{Na}_{2}$ EDTA and $5.57 \mathrm{~g}$ of $\mathrm{FeSO}_{4} \times 7 \mathrm{H}_{2} \mathrm{O}$ in water (the final volunie was led to 11 and heated to $100^{\circ} \mathrm{C}$ ). To prepare 1 l of an agar nutrient medium we mixed $100 \mathrm{ml}$ of the initial solution of macrosalts, $10 \mathrm{ml}$ of microsalts, $5 \mathrm{ml}$ of Fe-helat and corresponding quantities of agar, vitamins, hormones, hydrocarbons, etc.

Vitamin solutions were prepared just before experiments. Auxins were dissolved initially in a small quantity of ethanol and brought to the necessary volume with water under heating; cytokinin solutions were prepared by a dissolving of a corresponding cytokinin in a small volume of $0.5 \mathrm{~N} \mathrm{HCl}$ under heating with the following mixing with necessary amount of water.

Agar nutrient media (6-8 $\mathrm{g}$ of agar/l) brought to certain $\mathrm{pH}$ were autoclaved. Isolation and cultivation of mesophyll protoplasts from leaf discs of tobacco were realised by methods in detail described in protocol part of the book [9].

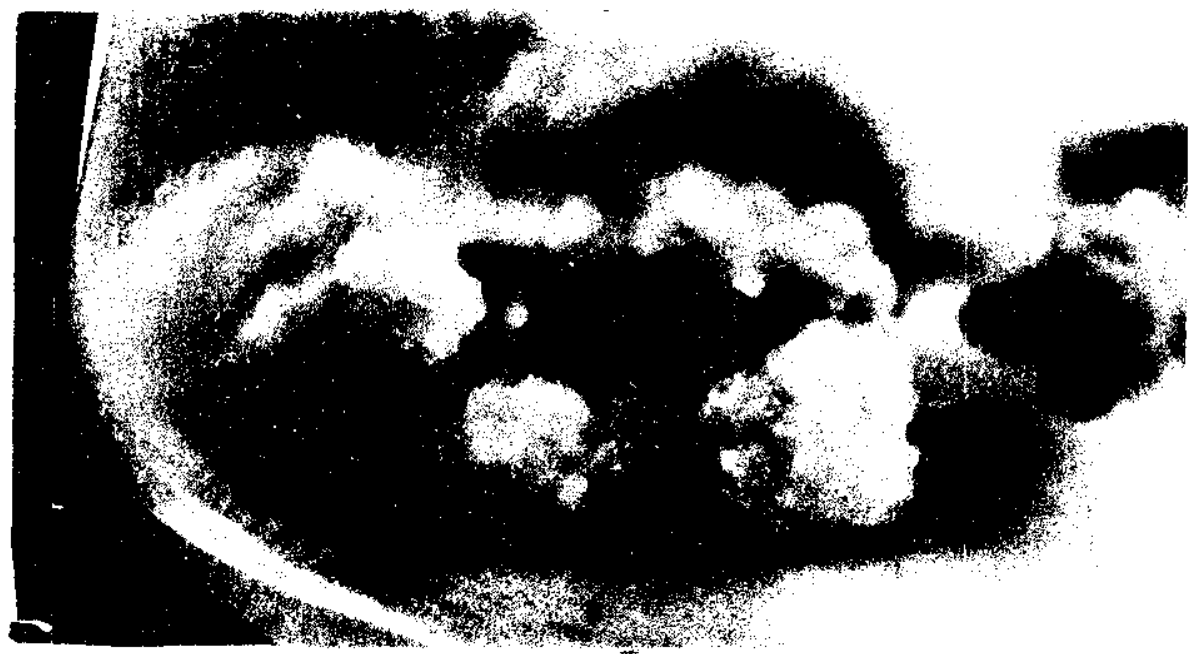

Fig. 1. Undifferentiated growing tobacio tissue (callus) received on the RMKV medium containing $0.1-0.5 \mathrm{mg} / 1 \mathrm{of}$ Triamelon 
Results and Discussion. It is known that for many kinds of family Solanaceae the formation of callus tissue can be induced with the medium containing $1 \mathrm{mg} / 1$ of auxin 2,4-D (2,4-dichlorphenoxyacetic acid) as well as organogenesis can be stimulated with cytokinin media $-1 \mathrm{mg} / 1$ of BAP (5benzylaminopurine, 6-benzyladenin). However, for some species the combination of auxins and cytokinins is necessary. If the ratio of auxin: cytokinin is more than one the callus initiation prevails over stem
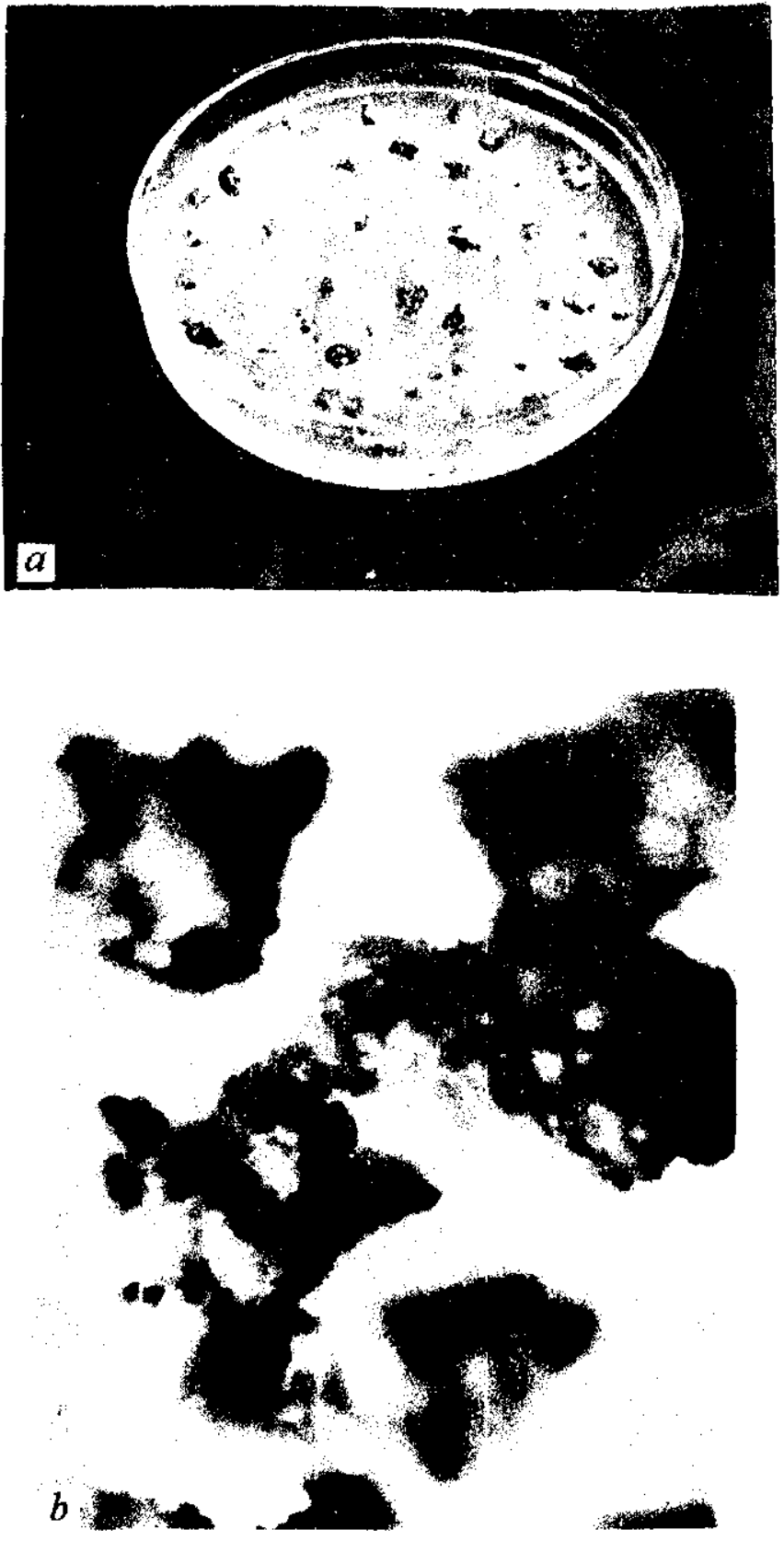

organogenesis. The contrary situation takes place when the ratio is less than 1 .

With the aim of more detailed investigation of chemical compounds we used both media with (NP, BK) and without (RMNO, RMKU, RMP, RMO, RMOP, RMB) above mentioned regularitics.

The possibility to substitute cytokinin by Triamelon was shown on 3 different media, that usually used for the formation and support of tobacco callus in regime of long term passing:

1) RMKU, where $0.1 \mathrm{mg} / 1$ of Triamelon mixed with $1 \mathrm{mg} / 1$ of NAA;

2) RMP, where $0.1 \mathrm{mg} / 1$ of Triamelon mixed with $0.1 \mathrm{mg} / 1$ of $2,4-\mathrm{D}$;

3) RMNO, where $0.05 \mathrm{mg} / \mathrm{l}$ of Triamelon mixed with $3.0 \mathrm{mg} / \mathrm{l}$ of NAA and with $0.1 \mathrm{mg} / 12,4-\mathrm{D}$.

So Triamelon can be combined both with natural auxins (IAA) and with synthetic analogues $(2,4-D$; NAA). At all combinations the growth and support of callus were observed (fig. 1). There has not been callus growth inhibition.

The next stage of our experiment was to check the action of synthetic compounds with the media of organogenesis induction. The root formation in cultured tobacco callus and at following-passing the formation of stem buds and then leaflets were observed on RMO medium containing a mixture of Triamelon $(1 \mathrm{mg} / \mathrm{l})$ and IAA $(2 \mathrm{mg} / \mathrm{l})$ (fig. $2, a)$.

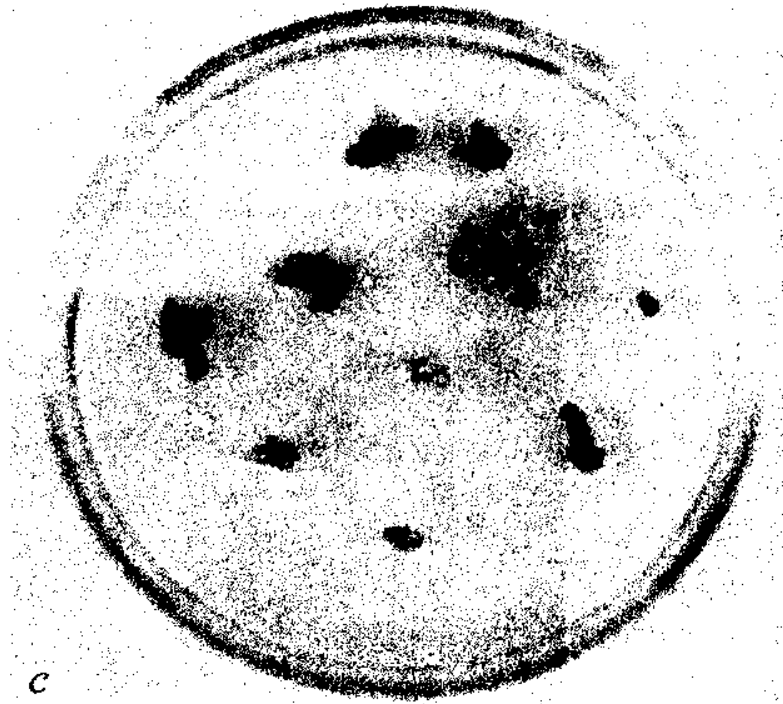

Fig. 2. The stem bud formation and the appearance of leaves on the RMO medium containing $1 \mathrm{mg} / 1$ of Triamelon and $2 \mathrm{mg} / 1$ of NAA (a); the bud formation of tobacco tissue on the RMOP medium containing $1.5 \mathrm{mg} / 1$ of Triamelon and $0.1 \mathrm{mg} / 1$ of NAA $(b)$; organogenesis in callus culture on the RMKU medium containting $2-5 \mathrm{mg} / \mathrm{l}$ of Triamelon and $1 \mathrm{mg} / 1$ of NAA $(c)$ 


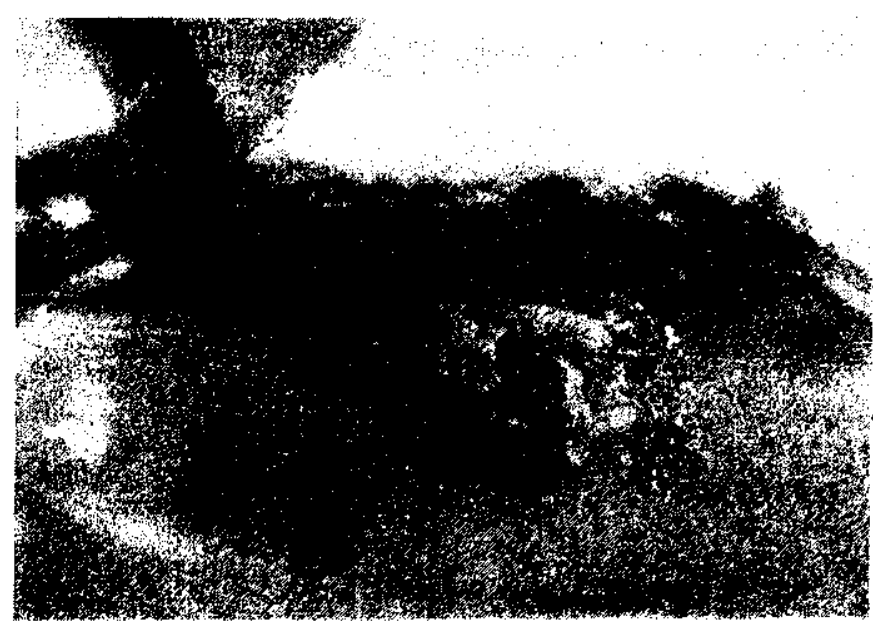

Fig. 3. The embryogenic callus on the RMKU medium containing $10-20 \mathrm{mg} / \mathrm{l}$ of Triamelon and $1 \mathrm{mg} / \mathrm{l}$ of NAA

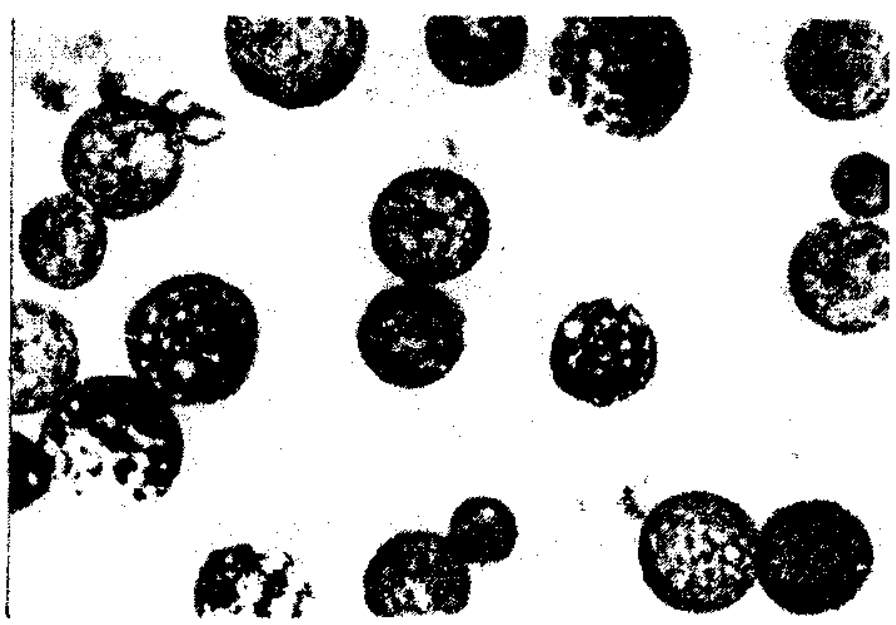

Fig. 4. The microscopic analysis of mesophyll protoplasts of tobacco (magnifying $=180$ times)
There was only a formation of buds on the RMOP medium (Triamelon $1.5 \mathrm{mg} / \mathrm{l}$ and $0.1 \mathrm{mg} / \mathrm{l}$ NAA) (fig. $2, b)$. When we used RMKU $(2.5 \mathrm{mg} / \mathrm{l}$ Triamelon and $/ \mathrm{mg} / \mathrm{I} \mathrm{NAA}$ ) plant-regenerants were noticed (fig. $2 \mathrm{c}$ ).

So we have found optimum concentrations of auxins and substance $N 2863$ (Triamelon) that like cytokinins can cause root formation and support conditions for meristematization of tissue and formation of stem buds. Also it should be noticed that under the influence of light callus became green because indicated concentration of Triamelon induced the synthesis of chlorophyll and formation of chloroplasts.

Previous works [9] as well as our investigations show the essential role of auxins presented in nutrient media for the formation of embryogenic structures. Decrease of concentrations of 2,4-D, NAA, IAA, CPAA or their absence in presence of cytokinins promoted the maturity of embryogenic callus with formation of solid globular structures embryoids and then of shoots.

On the contrary, prevention of embryoids maturity was observed on media, where proembryoids were passed in the presence of auxins. We have induced the embryogenesis on RMKU medium at higher concentrations of Triamelon $(10--20 \mathrm{mg} / \mathrm{l})$ and on RMP medium at certain combination Triamelon with artificial auxin (NAA) (fig. 3).

Also we have investigated the influence of Triamelon concentrations $(0.1-20 \mathrm{mg} / \mathrm{l})$ on the induction of cell division. Literature sources point out that this test can be considered as specific one for cytokinin activity. With this aim instead of kinetin indicated quantities of the preparation were added to Linsmaier and Skoog medium and callus culture of core parenchyma of tobacco stem was cultivated. The same media without kinetin and minimum enriched with kinetin served as control samples. Efficiencies of preparations were estimated by increase of biomass counted for dry and humid mass. So we suggest that Triamelon evinces the cytokinin activity at concentration $2 \mathrm{mg} / \mathrm{l}$ in the best way and under this conditions it is more effective than kinetin on $23 \%$.

In test experiments with mezophyll protoplasts of tobacco (fig. 4) the possibility to use Triamelon instead of kinetin on both W-5 medium (ussually applied for formation of cells' colonies) and MS medium (for induction of callus tissues formation and producing of plant-regenerants) was also demonstrated.

It is known that conditions for active growth of embryoids and connecting with it further elongation of stem (i. e. transition from meristematic tissue to phase of active growth) require essential changes in cultivation conditions with new nutrient media $[8,9$; $12-13$ ]. We have received a good result using $2-4$ consistent passages of embryogenic callus on the same RMOP medium. The only difference was that we took high concentrations of Triamelon $(2.0-5.0 \mathrm{mg} / 1)$ (fig. 5), and further placed callus tissue in medium $P$ without hormones (fig. $6, a$ ).

Also in the literature one can find that the regeneration of tobacco stem can be observed on 


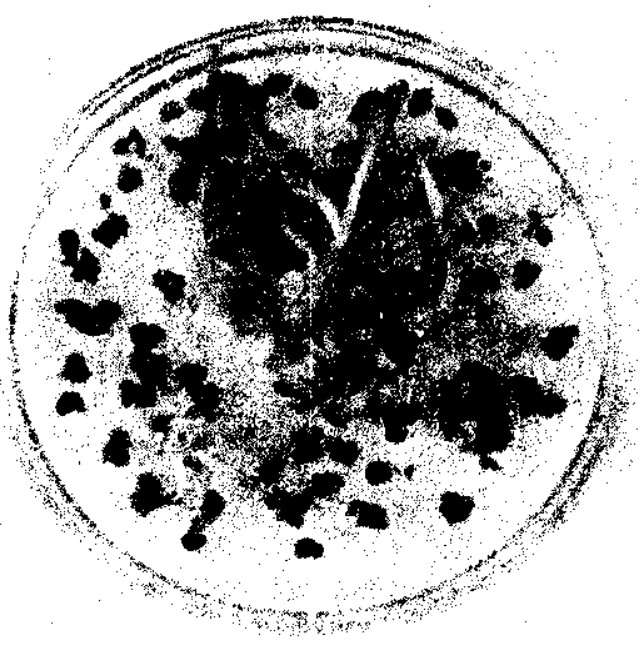

Fig. 5. Plant growth on the RMOP medium containing $5 \mathrm{mg} / 1$ of Triamelon and $0.1 \mathrm{mg} / 1$ of NAA

media containing no auxins, but enriched with cytokinins $[9,14]$. There was the appearants of plantregenerant in our experiment on RMB medium containing Triamelon $(5 \mathrm{mg} / \mathrm{l})$ instead of cytokinin BAP $(0.1-1.5 \mathrm{mg} / 1)$ (fig. $6, b)$. Then this test-tube plant with the aim of root formation was placed in $R M_{\text {min }}$ medium (without phytohormones) with $0.01 \mathrm{mg} / 1$ Triamelon (fig. 7, a). Results of the experiment are demonstrated on fig. $7, b$, where plant-regenerants grown with Triamelon are shown before planting in ground.

Screening of induction of callus formation and callus passing of wild species of tomato have been made on BK medium. In this medium to two auxins (NAA and 2,4-D) we added Triameion $(0.5 \mathrm{mg} / \mathrm{l})$ instead of kinetin. The same procedure was investigated on RMOP medium. Concentration of Triamelon was $1 \mathrm{mg} / 1$. To support the callus of cullural species of tomato we used RMKU medium with Triamelon $(0.2 \mathrm{mg} / \mathrm{l})$.

Thus, we have shown the first the possibility to use Triamelon for cultural works with tomato and potato tissues in media that are used for induction and long-term passing of tobacco and potato cultures as well as the possibility to combine Triamelon with phytohormones of auxin type (NAA, 2,4-D) in this

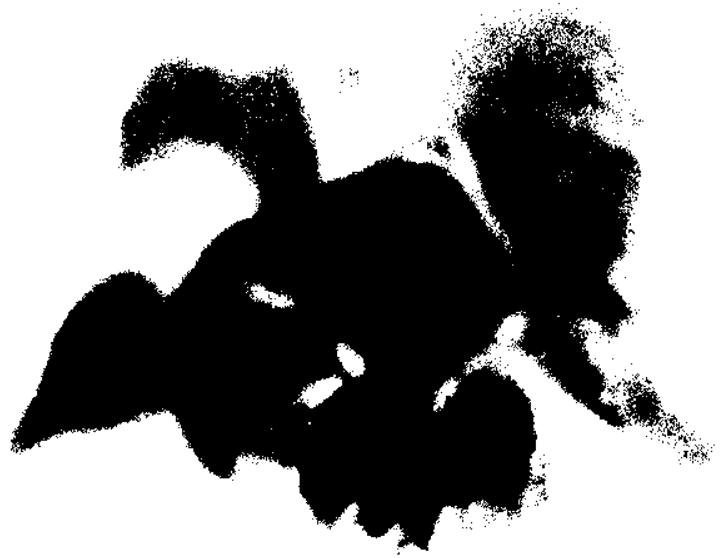

$a$

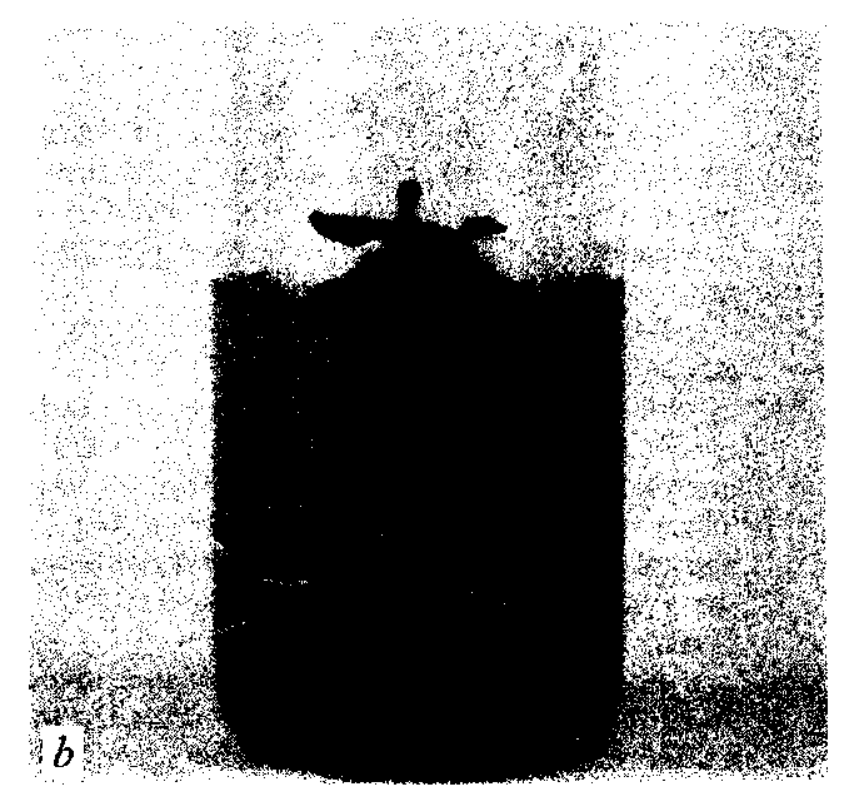

Fig. 6. Formation of the plant from the cmbryoid on $\mathrm{P}$ medium without phytohormones $(a)$; the regeneration of whole tobacco plant on the RMB medium containing $5 \mathrm{mg} / 1$ of 'Triamelon $(b)$

media. Screening the growth regulative activity of Ivin and its derivalives (Ivin-s, lvin-h) were made on callus cultures of potato.

It has been shown that in NP medium used for induction of growth and support in passage of potato callus Ivin $(0.05-10 \mathrm{mg} / \mathrm{l})$ taken instead kinetin stimulated growth of callus biomass comparing with control (NP medium with $1 \mathrm{mg} / 1$ of kinetin). The best results were received with concentration of Ivin $5 \mathrm{mg} / 1$. Besides, Ivin delaycd cells' ageing of callus 


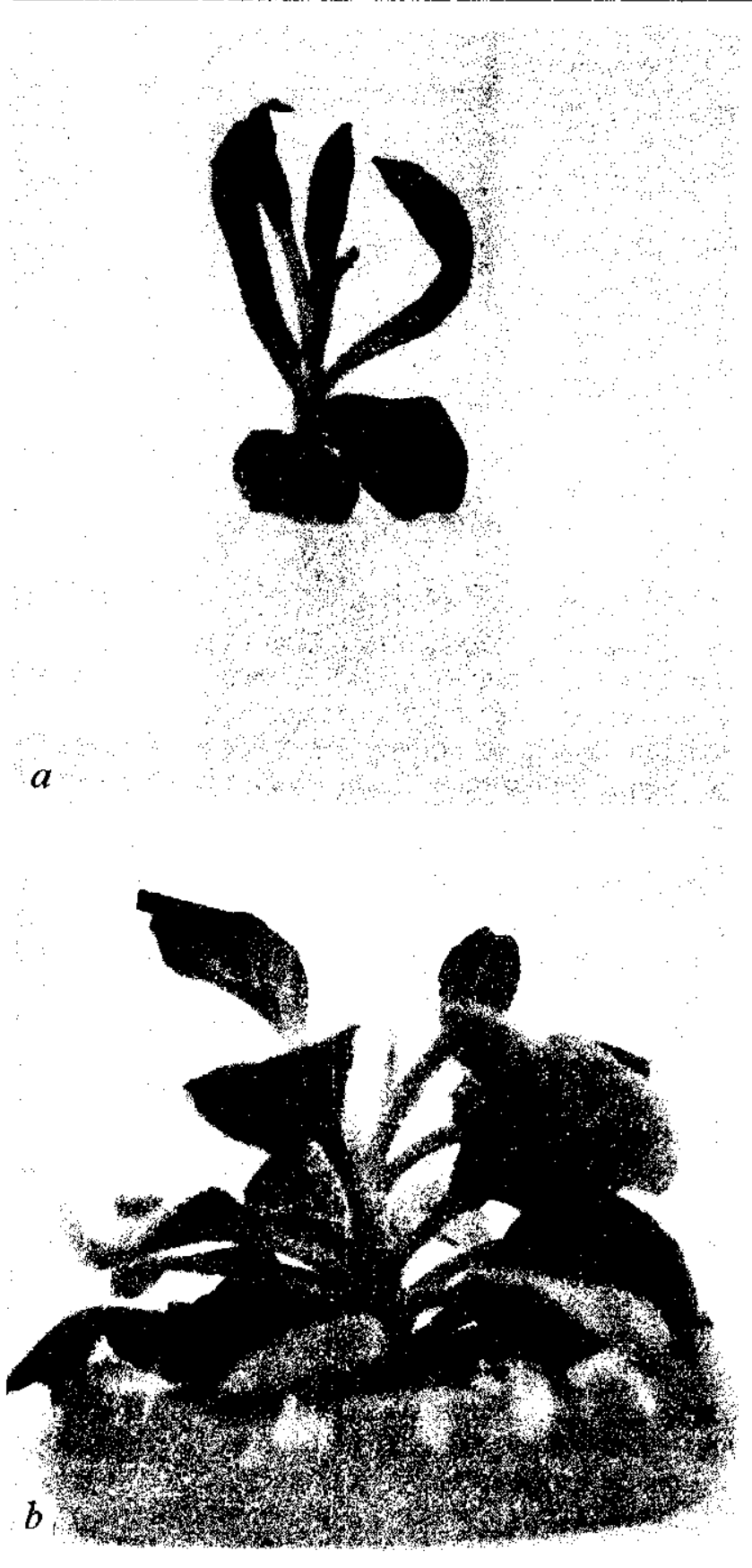

Fig. 7. The root formation on the $\mathrm{RM}_{\mathrm{min}}$ mediun containing $0.01 \mathrm{mg} / \mathrm{l}$ of Triamelori $(a)$; plant regenerants before the placing in ground $(b)$

tissue. That allows to keep callus in passage during 6 months without changing of a nutrient medium.

The chemical compound Ivin-s $(0.1-5 \mathrm{mg} / 1)$ was also tested with potato medium NP and on RMKU medium used early for tobacco callus. It has been

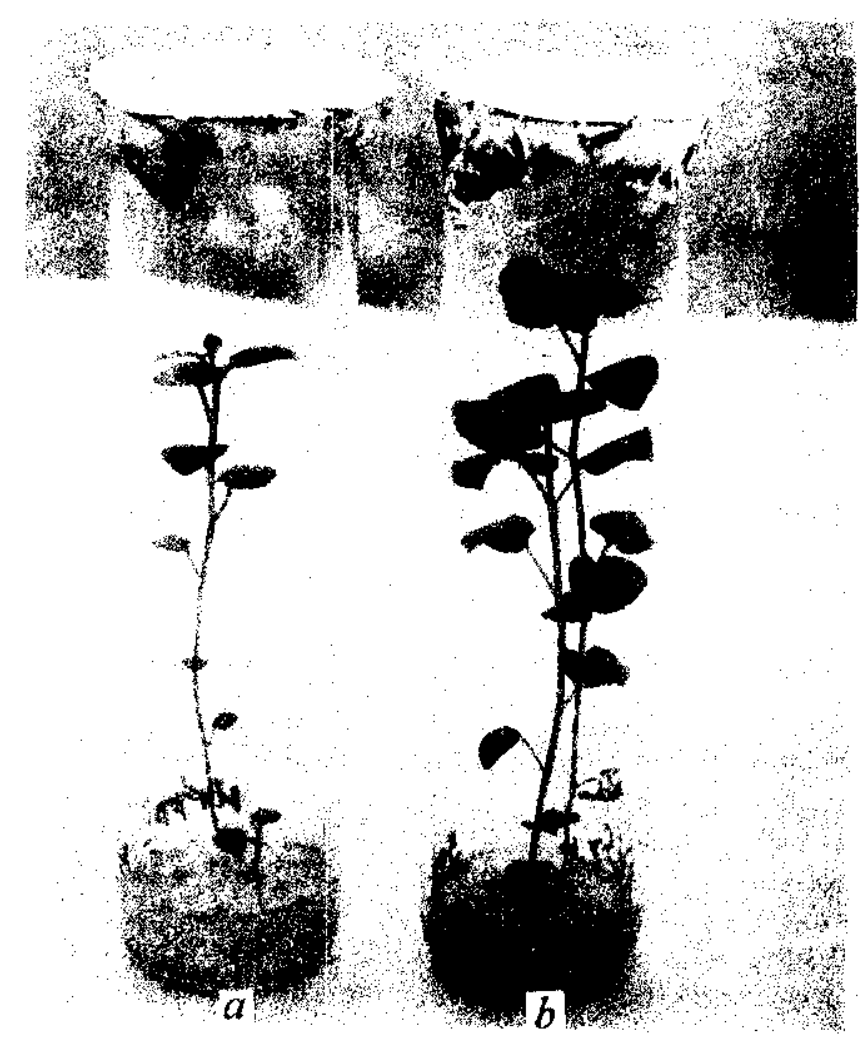

Fig. 8. Plant regenerants of potato derived from embryoids on the NP medium containing kinetin $(a)$ and $5-10 \mathrm{mg} / \mathrm{s}$ of Ivin-s instead of kinetin $(b)$

found that there was growth of callus mass at above mentioned concentrations. Moreover, much more intensive process was observed on RMKU medium for potato callus, which under light turned to dark green after 2 months period.

Ivin-h $(0.05-3 \mathrm{mg} / \mathrm{l})$ on $\mathrm{P}$ medium evinced the similar action. So, derivatives of Ivin increase the growth of callus biomass, delay the cell' ageing and activate photosynthesis in cells. Comparative studies of Ivin-s $(0.1-5 \mathrm{mg} / 1)$ and Triamelon $(5 \mathrm{mg} / 1)$ with potato medium NP showed that both preparations can be used instead of kinetin for callus growth and maturity. In the both cases callus turned to green after 40 days period under the influence of light, i. e., there was the activation of photosynthesis.

Ivin-s (concentration $5-10 \mathrm{mg} / \mathrm{l}$ ) was used on ST-2 medium for the induction of morphogenesis and the creation of potato plant-regenerants (fig. 8). Test-tube plants grown from the embryoids that were received on the medium containing Ivin-s showed a more powerful development $(b)$, than plants grown 
Comparative data of the stimlilation of root formation by synthetic substitutes of phytohormones

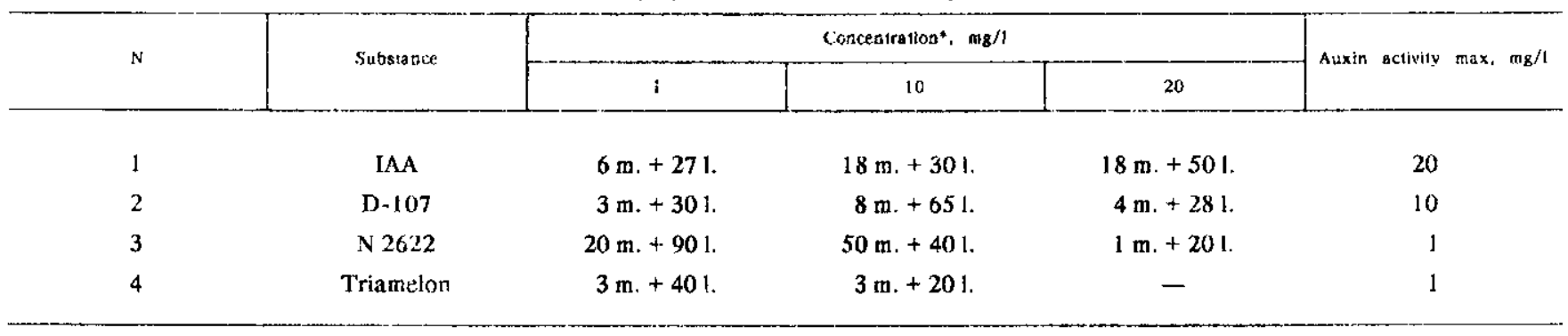

*m. - atatn root; 1. - lateral ront

with kinetin medium (a). The root formation on ST-3 medium without hormones was made.

Also the screening of Ivin and Ivin-s were made on callus culture of tobacco. Induction of callusogenesis was found on RMKU medium, containing $1 \mathrm{mg} / 1$ of Ivin or $2 \mathrm{mg} / 1$ of Ivin-s and on RMP medium $(0.2 \mathrm{mg} / \mathrm{l}$ of Ivin). There was the callus meristematization on RMOP medium, containing 5 $\mathrm{mg} / \mathrm{l}$ of Ivin-s. All experiments were carried out on nutrient media in which kinetin was substituted by Ivin or Ivin-s, combined with auxins (NAA; 2,4-D).

Action the chemical substance $\mathrm{N} 2622$ was investigated with the same model and the same medium, although instead of auxin-NAA ( $1 \mathrm{mg} / \mathrm{l})$ we used $1 \mathrm{mg} / 1$ of substance $N 2622$. So we combining it with cytokinin-kinetin. Appearance of leaf was observed after one month callus cultivation in darkness.

Thus we can conclude that synthetic chemical compounds (Triamelon (N 2863), Ivin, Ivin-s, N 2622) evince high biological activity. They can be used for works with cell' cultural and plant organs of family Solanaceae.

Experiments for screening of auxin activity with leaf cuttings of haricot in vivo determined three compounds possessing the auxin-like effect: D-107, substance $\mathrm{N} 2622$ and Triamelon (see table). Among the preparations the most significant activity (that was even more than IAA's one) was detected for substance $\mathrm{N} 2622$ at minimal concentration $(1 \mathrm{mg} / 1)$. Substance D-107 had similar effect with $10 \mathrm{mg} / 1$ and Triamelon shown the lowest activity in root formation tests.

Studying the influcnce of synthetic plant growth regulators on the germination of embryo axes of haricot seeds we found that Ivin and Methyur have essential cytokinin-gibberellin activities $[11]$, i. e. they increase significantly the germination energy of seeds of haricot reducing germination terms almost in 2 times. In these experiments Triamelon didn't show a phytohormone activity in the contrast of its above mentioned biological activity in vitro on Solanaceae cultures and preliminary data of its growth-promoting influences on melons' plants in vivo.

Our and derived from the literature data $[1,7$, $12,13,15$ ] witness that on the contrary to phytohormones synthetic plant growth regulators act upon both cells of undifferented and differented tissues and cells of different plant species not always in the same way. In the one case the synthetic preparation works as analogue of one phytohormone but under other conditions the same preparation can evince properties of another phytohormone. Thus some preparations have multifunctional properties. All of it complicates the interpretation of possible synthetic substances mechanisms of action in particularly when synthetic plant growth regulators have great differences in structure from the natural phytohormones.

For example, it has been suggested that synthetic auxins 1-NAA, 2-NOAA, 2,4-D demonstrate similar to IAA biological effects (though varied in quantitative values) despite of their structural differences, that accounts by common steric configuration (at least for some structural features). It allows the above mentioned regulators interact with a certain receptor [8]. High activities of 2,4-D and 2,4,5-T (even more than IAA) is explained so that of IAA's oxydase can't hydrolyse these artificial compounds [8]. Another hypothesis affirms that synthetic compounds prevent an oxidation of endogenic phytohormones that allows last ones demonstrate a maximum of their activity [7]. Different levels of activity for natural and synthetic compounds also could be connected with distinctive membrane permeabilities and transport mechanisms inside the cells and in intracellular space 
for such substances. Arrother question about non specifical action of synthetic auxins through increase of N-containing amino acid - tryptophar biosynthesis (the predecessor of IAA) or growth of free IAA concentration duc to induction of hydrolysis of auxinprotein complex by synthetic compounds are considering $[2,7]$.

Thus a great number of facts confirm non spesifical influence of synthetic plant growth regulators on plant cells, and especially those of them that differ in structure from natural compounds essentially.

Indeed if the specific receptors for recognition sites of struclure and specific fitting points of hormones inside cells really exist in the case of natural compounds (phytohormones) then one can suppose that the action of synthetic regulalors with «strange» structures is indirect and unified. Most probably they act unificationly by changing the active pool of endogenic phytohormones (either by transfer of their inactive forms to active ones or by non specifical activation of genes encoding the synthesis of phytohormones similar to the action of stress factors or by two mechanisms at the same time), that increase a growth and a maturity of plants ihrough the natural metabolic pathways.

The data concerning the influence of chemical preparations on cell division, biomass growth of yeast and fungi in cultural media 'submarsed fungus Pleurotus $s p$. and strains yeast: $N 563$ for alcoholic fermentation and bakers yeast U-1037). obtained in our experiments from numerous investigations can be indirect confirmation of this thesis.

It was found that no one of great number compounds (including and used those in this work) in physiological concentrations did not have marked influence on the indicated exponents.

We suppose that this phenomenon is connected with absence at above mentioned organisms adequate hormonal regulatory systen of growth and development, which contrary exists in plants.

In cells of undifferentiated and differentiated tissues and cells of various plant species different «targets» (or their absence at all) for synthetic regulators with non specific configurations can be realised and so there are various biological effects (or their absence).

Their appearances connecied with a multiplicity of cell regulation systems. It is known that undifferentiated cells have more simple regulation system comparing with differentiated ones and specializated cells of various plant species have different homeostaze (i. e., the constancy of intracellular medium) and so different types of regulation for its support. In as much as in celis of higher organisms there are polycomponent principle of regulation and not one but several compounds act simultaneously in the regulatory process $[16-18]$, we can suppose that synthetic growth regulators increase the formation of active pool of all compounds participating in such process either everyone of separately, or one after another on cascade mechanism.

Analysing differences of regulators' action in vivo and in vitro also it should be noticed that multielemental ompositions of nutrient media are selected by their authors with the aim to provide maximum and specific activities of exogenic phytohormones or their close synthetic substitutes. Therefore synthetic compounds with other chemical reactivities can interact with chemical components of medium (sometimes it contains over 20 elements) and as result of such interactions change their structural and biological properties.

Differences in the influence of growth regulators on differentiated and undifferentiated cells can bc explained only with further experimental investigations. But despite of the differences the use of growth regulators as substitutes of phytohormones are very perspective not only for studies of morphogenetical processes in vitro, but for practical purposes too (even if for solution of limited tasks).

Concerning the perspectives of use selected synthetic growth regulators in present work, we conclude that their characteristics on the all criterions entirely suit for the practical application.

Ivin and its derivatives (complexes of Ivin with succinic - Ivin-s, hydrochloric - Ivin-h, phosphoric - Ivin-p or boric acids - Ivin-b) are widely used in a plant-growing to increase a productivity of some agricultural plants [5]. Using these substances in agriculture is permitted by State Chemical Committee of Ukraine.

Also use of Methyur and Triamelon enlarges rapidly. Toxities of chosen preparates and their derivatives are lower than for known growth regulators.

That fact can be explained because chemical structures of these compounds are close to natural pyrimidines (for example, Methyur, substance D-107, $N$ 2622). On the other hand, Ivin and Triamelon have no toxic groups. Manufacturing and commercial costs of investigated compounds are 10-100 time lower then for foreign ones. An important advantage of suggested compounds is a solubility in water. Although it should be noticed that some of them can disintegrate in aqueous solutions at a long-term storage.

The data of this work also confirm the possibility to use selected synthetic growth regulators not only 
for purposes of plant-growing, but for biotechnology in vitro.

\section{В. А. Циганкюва, Я. Б. Блюм}

Скринінг та особливості біологічної дії синтетичних регуляторів росту рослин

Резюме

У процесі біологічного скринінгу синтетичних препаратів, які виявляють ріст-регулюючу активність у культурах тканин іп vitro $i$ на рослинах in vivo, відібрано $n^{\prime}$ ять прәnаратів $я$ к перспективних захінників фітосормонів: Iвін (N-oxide-2,6dimethylpyridine) 3 переважною цитокініновою активністю іп vitro $i$ цитокінін-гібереліновою икімизністо іп vivo; Mетіур (Na-derivative 6-methylthyouracyl) з вирахеною цитокінін-гібереліновою акпивністю in vivo; Тріанелон (iadide tris $(2,2-$ trimethylammoniummethyl phosphate)! - з цитокінін-ауксиновою активністю in vitro; D-I07 (1-acetylamino-1-acetylthyo-2охо-2-phenylethan) 3 ауксиноподібним ефектом ma № 2622 (derivative tetrahydrothyophendoixide) з яскраво вираженою ауксиновою активністю in vivo. Запропоновано мојель опосередкованої дї регуляторів росту рослии через фітогормони.

\section{В. А. Цыганкова, Я. Б. Блюм}

Скрининг и особенности биологическиго действия синтетических регуляторов роста растений

Резюме

B проиессе биологического скрининга синтетичских препаратов с рост-регулірующей актияностьк в культурах тканей іп vitro u ha pacmenusx in vivo bulli oтобраны nsmb npenapamos как перспективные заменители фитогормонов: Ивин ( $N$-охіdе 2,6-dimethylpyridine) с преобладающей цитокининовой активностью in vitro и цитокинин-гиббереллиновой in vivo; Метиур (Na-derivative 6-methylthyouracyl) с выраженнай циттокинин-гиббереллиновой активностько in vivo; Триамелон (iodide tris (2,2-trimethylammoniummethyl phospate $)-c$ uитокьнин-ауксиновой активностью in vitro; D-I07 (I-acetylamino-1-acetylthyo2-oxo-2-phenylethan) с ауксиноподобньм еффектол и № 2622 (derivative tetrahydrothyophendioxide) $c$ ярко выраженной ауксиновой актизностин іп vivo. Предиожена жодель опосредованного действия регуляторов роспа растений через фитогормоны.

\section{REFERENCES}

1. Mel nikov N. N., Baskakov Yu. A., Bokarev K. S. Chemistry of herbicides and plant growth stimulators.-Moscow: Goskhimizdat, $1954 .-382 \mathrm{p}$.
2. Chemical regulation of growth and maturity of plants // Book of articles of Institute of Biology of Latvian Academy of Sciences.-Riga: Zinatne, 1969.-196 p.

3. Gamborg K. Z., Kulaeva O. N., Muromtsev G. S. et al. Plant growth regulators.--Moscow: Kolos, $1979 .-246 \mathrm{p}$.

4. Dorffling $K$. Das Hormonsystem der pfianzen.-Stuttgard: Springer, 1982.-304 p.

5. Kukhar V. P., Karabanov Yu. V., Pavlenko A. F. et al. A new growth regulator - Ivin. - Physiologically active compounds. Kiev: Naukova dumka, 1986. -V. 18.-P. 3-14.

6. Kalilnin F. L. Application of growth regulators in agriculture.Kiev: Urozjay, $1989,-168 \mathrm{p}$.

7. Butenko R. G. The culture of isolated tissues and a physiology of the plant morfogenesis.-Moscow: Nauka, 1964.-272 p.

8. Polevay v. V. Phytohormones.-Leningrad: Univ. press, 1982.-P. 249.

9. Sidorov V. A., Piven N. M., Gleba Yu. Yu., Sytnik K. M. Somatic hybridization of the Solanaceae family.-Kiev: Naukova dumka, 1985.-130 p.

10. Turetskaya $R$. H. A method for the determination of root formating activity of growth compounds // Dokl. Akad. Nauk. Russia.-1947.-57, N 3.-P. 295-298.

11. Varshavskaya V. B. Ideas of N. G. Kholodniy abou1 plant growth regulators in agricultural practice // Ukr. Bot. J. (Kiev).-1982.-32, N 3.-P. 87-96.

12. Kalilnin F. L, Sarnatskaya V. V., Polichuk V. E. Methods of cultural tissues in piant physiology and blochemistry.-Kiev: Naukova dumka, 1980.-488 p.

13. Sheveluha $V$. S. Plant growth and its regulation in ontogenesis.-Moscow: Kolos.-1992,-594 p.

14. Nicotiana: Procedures for experimental use // Technical bulletin.-New York: Department of Agriculture, 1979.N 586.-P. 124.

15. Michalchuk C., Ribnitsky D. M., Cooke T. Y., Coken J. D. Regulation of indole-3-acetic acid biosyrthetic pathways in carrot cell cultures // Plant Physiol. (Russia) . - 1992.-100.P. $1346-1553$.

16. Nickel $L$. G. Velsicol Chemical. Controlling Biological Behavior with Chemicals // Plant Growth Regulators. Reprinted from Chemical and Ingineering News.--1978.--56, N 9.-P. 1834.

17. Nickel $L . G$. Plant growth reguiators. Agricaltural Uses.-Berlin: Springer, 1982.-191 p.

18. Plant disease control. Resistance and susceptibility / Ed. R. C. Staples et al.-Moscow: Kolos, 1984. -287 p.

Received 10.06.97 